Ruswandi, D. · J. Supriatna · E. Suryadi · N.P. Indriani $\cdot$ N. Wicaksana $\cdot$ M. Syafii $\cdot$ Y. Yuwariah

\title{
Evaluasi kegenjahan dan daya hasil jagung manis hibrida Indonesia menggunakan analisis GGE biplot pada lingkungan yang berbeda
}

Sari. Uji multilokasi merupakan fase yang penting dalam menyeleksi hibrida jagung yang stabil pada lingkungan yang luas dan menyeleksi hibrida superior untuk lokasi spesifik. Tujuan penelitian ini yaitu untuk mengetahui kegenjahan dan daya hasil hibrida Padjadjaran, serta menentukan interaksi genotip dengan lingkungan ( $\mathrm{G} \times \mathrm{E})$, stabilitas, dan adaptabilitas karakter kegenjahan hibrida Padjadjaran di tiga lokasi selama dua musim yang berbeda di Jawa Barat. Rancangan percobaan yang digunakan adalah Rancangan Acak Kelompok dengan delapan belas perlakuan yang terdiri dari enam belas hibrida Padjadjaran dan dua kultivar cek. Percobaan dilaksanakan selama dua tahun berturut- turut yaitu tahun ke-1 (Maret sampai Juli, 2014) dan tahun ke-2 (Maret sampai Juli, 2015) di tiga lokasi di Jawa Barat, yaitu: Jatinangor - Sumedang, Lembang - Kabupaten Bandung Barat, dan Wanayasa Kabupaten Purwakarta. Uji lanjut yang digunakan untuk mengetahui perbedaan nilai rerata kegenjahan dan daya hasil digunakan analisis Duncan Multiple Range Test (DMRT), sedangkan untuk menentukan interaksi G x E, stabilitas, dan adaptabilitas menggunakan Genotype plus Genotype $x$ Environment (GGE) biplot. Hasil memperlihatkan bahwa analisis GGE dapat menentukan interaksi G x E, stabilitas, dan adaptabilitas jagung manis hibrida Indonesia di Jawa Barat secara akurat. Model GGE disarankan untuk dapat digunakan sebagai aplikasi analisis untuk perilisan hibrida unggul di Indonesia oleh Kementerian Pertanian.

Kata kunci: Adaptabilitas · Interaksi G x E, kegenjahan · Stabilitas

\section{Short duration and yield potential evaluation in Indonesian sweetcorn hybrids using GGE biplot analysis at different environments}

\begin{abstract}
Multi-environment testing is an important stage to select stable hybrid for broad environment and to select superior hybrid for a specific environment. To determined G x E (Genotype $\mathrm{x}$ Environment) interaction, stability and adaptability of Padjadjaran sweet corn in Indonesia, sixteen new Padjadjaran sweetcorn hybrids and two commercial hybrids were tested in three locations for two different seasons in West Java, Indonesia. Duncan multiple range was used to elaborate the difference between sweetcorn hybrids for short duration and yield, while Genotype plus Genotype $x$ Environment (GGE) biplot analysis was used to determine $G \times$ E interaction, stability, and adaptability. Results showed that GGE analysis was accurately determined G x E interaction, stability, and adaptability of Indonesian sweet corn in West Java. The GGE model is suggested to implement as a tool for Ministry of Agriculture to release superior hybrid in Indonesia.
\end{abstract}

Keywords: Adaptability · G x E interaction · Short duration · Stability

Diterima : 25 Maret 2021, Disetujui : 22 Juli 2021, Dipublikasikan : 1 Agustus 2021

DOI: https://doi.org/10.24198/kultivasi.v20i2.32748

${\text { Ruswandi, D. }{ }^{1} \text { J. Supriatna }}^{2}$. E. Suryadi ${ }^{3}$ N.P. Indriani ${ }^{1} \cdot$ N. Wicaksana ${ }^{1} \cdot$ M. Syafii ${ }^{4}$. Y. Yuwariah ${ }^{1}$

${ }^{1}$ Universitas Padjadjaran, Fakultas Pertanian, Bandung-Indonesia,

2 Universitas Islam Negeri Sunan Gunung Djati, Bandung,

${ }^{3}$ Universitas Padjadjaran, Fakultas Teknologi Industri Pertanian, Bandung-Indonesia,

4 Universitas Singaperbangsa Karawang, Fakultas Pertanian, Karawang, Indonesia

Korespondensi: d.ruswandi@unpad.ac.id 


\section{Pendahuluan}

Jagung manis merupakan komoditas pertanian yang strategis dikembangkan di Indonesia. Komoditas ini memiliki kandungan nutrisi yang lengkap seperti karbohidrat, protein, vitamin, dan beragam mineral penting lainnya (Ruswandi et al., 2016; Silmi dan Chozin, 2013). Kebutuhan jagung manis semakin meningkat dari tahun ke tahun, namun belum diikuti oleh produksi yang mencukupi dan produktivitas masih rendah (Ruswandi et al., 2016).

Produksi dan produktivitas jagung manis dapat ditingkatkan dengan penggunaan varietas hibrida berumur genjah, peningkatan produktifitas lahan, dan rotasi kultivar hibrida berumur genjah yang adaptif terhadap lokasi dan musim tanam (Ruswandi et al., 2020). Kunci sukses dari strategi ini adalah adanya varietas hibrida jagung manis genjah yang berdaya hasil tinggi dan adaptif terhadap berbagai pola tanam dan musim.

Karakter kegenjahan merupakan salah satu karakter penting varietas jagung manis unggul di Jawa Barat, Indonesia. Karakter kegenjahan jagung dapat diamati beradasarkan umur anthesis malai (Ruswandi et al., 2020). Jagung dengan kriteria umur sangat genjah memiliki umur anthesis kurang dari 38 hari setelah tanam (hst), kriteria umur sangat genjah hingga genjah berkisar antara 38-41 hst, kriteria umur genjah berkisar antara 41,1-44 hst, kriteria umur genjah hingga sedang berkisar antara 44.1-47 hst, kriteria umur sedang berkisar antara 47,1-50 hst, kriteria umur sedang hingga lambat antara 50,153 hst, kriteria umur lambat berkisar antara 53,156 hst, kriteria umur lambat hingga sangat lambat berkisar antara 56,1-59 hst dan kriteria umur sangat lambat yaitu lebih dari 59 hst.

Pada umumnya jagung manis ditanam di persawahan tadah hujan pada awal ataupun akhir musim hujan saat ketersediaan air tidak cukup untuk mengairi tanaman padi namun masih cukup untuk kebutuhan jagung. Karakter umur genjah merupakan karakter kompleks, poligenik, dan dipengaruhi lingkungan. Seleksi hibrida jagung manis berumur genjah hanya mungkin dilakukan bila tersedia informasi interaksi genotipe dengan lingkungan $(\mathrm{G} \times \mathrm{E})$ ( Mace et al., 2013; Ruswandi et al., 2020).

Tahapan penting seleksi hibrida unggul di Indonesia adalah pengujian multilokasi.
Pengujian multilokasi dilakukan untuk mengkaji interaksi hibrida $x$ lingkungan dan menyeleksi hibrida stabil pada berbagai lingkungan atau beradaptasi pada lingkungan spesifik (Balestre et al., 2009). Yan et al. (2000) menjelaskan pentingnya identifikasi faktor penyebab interaksi G $x$ E dalam menentukan tujuan pemuliaan, kondisi ideal pengujian, dan menentukan varietas regional yang memiliki adaptasi yang baik.

Terdapat beberapa metode statistik dalam menentukan stabilitas dan adaptibilitas varietas. Analisis AMMI (Additive main effects and multiplicative interaction model) adalah metode statistik multivariat yang digunakan untuk mengkaji interaksi $\mathrm{G} \times \mathrm{E}$ berdasarkan biplot (Aruna et al., 2016). Yan et al. (2000) memodifikasi analysis AMMI menjadi GGE biplot (Genotype and Genotype-Environment Interaction) untuk mempelajari interaksi G x E. Analisis GGE mengelompokkan efek genotipe yang merupakan efek aditif dalam analisis AMMI, bersama-sama dengan interaksi $\mathrm{G}$ x E dan menganalisis efek tersebut dengan komponen utama (principal components, PC). Keunggulan teknik ini dibandingkan analisis AMMI 1 dan AMMI2 mega-environment adalah biplot selalu menjelaskan proporsi tengah dari jumlah kuadrat genotipe + genotipe $x$ lingkungan $(G+G \times E)$. Hal ini menjadikan GGE biplot lebih akurat dibandingkan AMMI 1 dan lebih praktis dibandingkan AMMI 2 megaenvironment ( $\mathrm{Rad}$ et al., 2013). Penggabungan efek genotipe tersebut merupakan strategi yang berguna dalam menyeleksi genotipe superior yang stabil dan produktif serta merekomendasikan genotipe spesifik lingkungan. Adapun tujuan studi ini adalah untuk mempelajari interaksi G x E dan stabilitas kegenjahan hibrida jagung manis di lokasi dan musim yang berbeda di Jawa Barat.

\section{Bahan dan Metode}

Percobaan dilaksanakan selama dua tahun berturut-turut, yaitu tahun ke-1 (Maret sampai Juli, 2014) dan tahun ke-2 (Maret sampai Juli, 2015) di tiga lokasi di Jawa Barat, yaitu: Jatinangor - Sumedang, dengan ketinggian 750 $\mathrm{m}$ di atas permukaan laut (dpl); LembangKabupaten Bandung Barat (1200 m dpl); dan Wanayasa-Kabupaten Purwakarta (600 m dpl). Hibrida yang digunakan adalah enam belas 
hibrida jagung manis Padjadjaran dan dua kultivar cek yaitu varietas Sweet Boy dan BISI Sweet. Materi genetik tersebut adalah: G1 (BS= BISI Sweet), G2 (SB= Sweet Boy), G3 (15 x 17), G4 (22 x 17), G5 (24 x 17), G6 (25 x 17), G7 (26 x 17), G8 (30 x 17), G9 (31 x 17), G10 (32 x 17), G11 (33 x 17), G12 (4 x 17), G13 (41 x 17), G14 (43 x 17), G15 (46 x 17), G16 (47 x 17), G17 (52 x 17), dan G18 $(9 \times 17)$. Materi genetik tersebut ditanam di tiga lokasi selama dua musim berdasarkan rancangan rancangan acak kelompok dengan tiga ulangan. Model linier untuk setiap lokasi pengujian mengikuti metode Hallauer et al. (2010). Karakter kegenjahan yang diamati adalah umur malai (hst), dengan menghitung jumlah hari dari waktu penanaman hingga polen pada tasel pecah pada $50 \%$ populasi genotype yang diuji. Sampling dilakukan pada setiap genotipe sebanyak 10 sampel secara acak.

Berdasarkan pengujian $\mathrm{F}$ pada analisis varians tunggal, apabila menunjukkan perbedaan nyata maka karakter-karakter yang diamati memberikan variasi yang nyata setiap lokasinya. Homogenitas varians galat dari keenam lingkungan tumbuh (3 lokasi selama dua musim) diidentifikasi dengan uji Bartlett (Hallauer et al., 2010). Apabila $\chi_{\text {hit }}^{2}>\chi_{\text {tabel }}^{2}$ maka galat tidak homogen dan pengujian dilakukan terpisah, tetapi bila $\chi_{\text {hit }}^{2}<\chi_{\text {tabel }}^{2}$, maka varians galat adalah homogen sehingga dapat dilakukan uji gabungan (Hallauer et al., 2010). Analisis gabungan didasarkan model analisis yang dideskripsikan oleh Hallauer et al., (2010). Berdasarkan model linier tersebut disusun tabel analisis varians gabungan. Pengujian $F$ yang menunjukkan perbedaan nyata diantara nilai rerata pengamatan (nilai $\mathrm{F}$ hitung lebih besar dari $\mathrm{F}_{0,05}$ ) maka dilakukan uji lanjut Duncan Multiple Range Test (DMRT) pada taraf nyata 5\%.

Analisis GGE biplot dinyatakan sebagai:

$$
Y_{i j}-\beta_{j}=\alpha_{1} \varepsilon_{i 1} \eta_{j 1}+\alpha_{2} \varepsilon_{i 2} \eta_{j 2}+\varepsilon_{i j}
$$

dimana Yij adalah nilai genotipe kombinasi (galur murni ataupun hibrida F1) antara galur ke $i$ dan tester ke $j$ untuk karakter yang diuji; $\beta_{j}$ rerata nilai semua kombinasi dengan tester ke $j$, $\alpha_{1}$ dan $\alpha_{2}$ adalah nilai tunggal untuk PC1 dan PC2. $\varepsilon_{i 1}$ dan $\varepsilon_{i 2}$ adalah eigen vektor PC1 dan PC2 untuk galur ke $i$ (entry); $\eta_{j 1}$ dan $\eta_{j 2}$ adalah eigen vektor PC1 dan PC2 untuk tester ke $j$; $\varepsilon_{i j}$ adalah sisaan model untuk galur ke $i$ dan tester ke j (Hoyos-Villegas et al., 2016). Nilai PC kemudian diekstrak dan dianalisis kebermaknaannya berdasarkan metode Kaya et al. (2002) yang dimodifikasi. Jika komponen Interaction Principal Component Analysis (IPCA) yang bermakna adalah IPCA-1, maka model yang berlaku adalah GGE-1. Tetapi bila komponen IPCA-1 dan IPCA-2 bermakna, maka model yang berlaku adalah GGE-2. Sedangkan bila tidak satupun komponen IPCA yang bermakna, maka model yang berlaku adalah GGE-0. Interpretasi hasil analisis GGE didasarkan pada grafik biplot yang dikontruksi dari nilai rata-rata dan nilai skor IPCA atau antar nilai skor IPCA. Analisis varians gabungan, analisis model GGE, dan GGE biplot dilakukan dengan bantuan software PB Tools yang dikembangkan oleh International Rice Research Institute (2016) dan tersedia di www.bbi.irri.org.

\section{Hasil dan Pembahasan}

Delapan belas hibrida yang diuji pada tiga lokasi selama dua musim memperlihatkan penampilan hasil yang berbeda sebagaimana yang ditunjukkan oleh rentang dan nilai rataratanya yang bervariasi (Tabel 1). Hal ini menunjukkan bahwa terdapat perbedaan kondisi optimal bagi pertumbuhan hibridahibrida tersebut pada ke-6 lingkungan tumbuh yang berbeda.yang ditunjukkan oleh rentang dan nilai rata-ratanya yang bervariasi (Tabel 1). Hal ini menunjukkan bahwa terdapat perbedaan kondisi optimal bagi pertumbuhan hibridahibrida tersebut pada ke-6 lingkungan tumbuh yang berbeda.

Tabel 1. Kisaran, rerata, dan standar deviasi untuk kegenjahan pada hibrida jagung manis Indonesia di Jawa Barat

\begin{tabular}{lcc}
\hline \multirow{2}{*}{ Lokasi } & \multicolumn{2}{c}{$\begin{array}{c}\text { Umur Malai } \\
\text { (Hari Setelah Tanam) }\end{array}$} \\
\cline { 2 - 3 } & Kisaran & $\begin{array}{c}\text { Rerata } \pm \\
\text { Standar Deviasi }\end{array}$ \\
\hline Jatinangor, Musim 1 (E1) & $60-74$ & $66,44 \pm 3,68$ \\
Jatinangor, Musim 2 (E2) & $57-70$ & $65,54 \pm 2,23$ \\
Lembang, Musim 1 (E3) & $76-78$ & $76,07 \pm 0,33$ \\
Lembang, Musim 2 (E4) & $69-83$ & $75,22 \pm 3,33$ \\
Wanayasa, Musim 1 (E5) & $56-67$ & $63,00 \pm 1,43$ \\
Wanayasa, Musim 2 (E6) & $57-66$ & $62,46 \pm 2,06$ \\
\hline
\end{tabular}


Tabel 2. Analisis varian gabungan kegenjahan hibrida jagung manis Indonesia.

Umur Malai

\begin{tabular}{lrc} 
Sumber Variasi & DB & $\begin{array}{c}\text { Kuadrat Nilai } \\
\text { Tengah }\end{array}$ \\
\hline Lingkungan (E) & 5 & $1780.5679^{* *}$ \\
Hibrida (G) & 17 & $25.0189^{* *}$ \\
Hibrida x & 85 & $10.9705^{* *}$ \\
lingkungan (G x E) & & \\
Eror & 204 & 4.2542 \\
\hline
\end{tabular}

Keterangan: ** dan * masing-masing adalah berbeda nyata pada tingkat kemungkinan 0,01 dan 0,05 , ns adalah tidak berbeda nyata, DB adalah derajat bebas.

Berdasarkan analisis gabungan diketahui interaksi genotipe dengan lingkungan tumbuh untuk karakter kegenjahan (Tabel 2). Interaksi tersebut mencakup interaksi genotipe dengan musim dan lokasi. Karakter kegenjahan seperti munculnya tongkol dan malai pada jagung manis sangat penting, karena semakin cepat muncul tongkol maka serbuk sari bunga jantan akan segera menyerbuki, dengan demikian tongkol segera terisi penuh dan semakin cepat pula waktu panen. Waktu panen pada jagung manis dapat dimulai dari 18 - 24 hari setelah penyerbukan tongkol oleh serbuk sari (Rubatzky dan Yamaguchi, 1998).

Munculnya tongkol dan malai jagung manis dipengaruhi oleh faktor temperatur. Jagung manis merupakan tanaman hari pendek yang pembungaannya tergantung pada penyinaran dan temperatur, apabila mendapatkan penyinaran dan temperatur optimum maka munculnya tongkol dan penyebaran serbuk sari juga akan optimum (Hallauer dan Carena, 2009). Subandi et al. (2003) menjelaskan bahwa kegenjahan, yang ditandai munculnya tongkol, dipengaruhi oleh temperatur optimum $24-30{ }^{\circ} \mathrm{C}$. Perbedaan ketinggian tempat menyebabkan perbedaan suhu sehingga menyebabkan perbedaan umur tanaman (Nurmala et al., 2015).

Interaksi genotipe dengan lingkungan yang nyata pada karakter kegenjahan seperti munculnya malai ditampilkan pada Tabel 2 . Analisis Varians gabungan menunjukkan bahwa terdapat interaksi antara hibrida (G) dengan lingkungan (E). Nilai rerata kegenjahan untuk setiap lingkungan dapat dilihat pada Tabel 3, sedangkan nilai rerata daya hasil untuk setiap lingkungan dapat dilihat pada Tabel 4.

Tabel 3. Nilai rerata kegenjahan (hst) pada hibrida jagung manis di Jawa Barat

\begin{tabular}{|c|c|c|c|c|c|c|c|c|c|c|c|c|}
\hline Hibrida & \multicolumn{2}{|c|}{ E1 } & \multicolumn{2}{|l|}{ E2 } & \multicolumn{2}{|l|}{ E3 } & \multicolumn{2}{|l|}{ E4 } & \multicolumn{2}{|l|}{ E5 } & \multicolumn{2}{|c|}{ E6 } \\
\hline (G1)BS & 66.33 & cde & 64.67 & $a b$ & 76.00 & $\mathrm{~b}$ & 73.67 & $a b$ & 59.67 & $\mathrm{~b}$ & 63.00 & a \\
\hline (G2) SB & 64.33 & def & 62.33 & $\mathrm{~b}$ & 76.00 & $\mathrm{~b}$ & 70.33 & $\mathrm{~b}$ & 63.33 & a & 58.00 & $b$ \\
\hline (G3) SR15 x SR17 & 62.67 & ef & 66.67 & a & 76.00 & $\mathrm{~b}$ & 74.33 & $a b$ & 63.67 & a & 63.00 & a \\
\hline (G4) SR22 x SR17 & 68.00 & bcd & 65.67 & $a b$ & 76.00 & $\mathrm{~b}$ & 78.33 & $\mathrm{a}$ & 62.67 & a & 63.67 & a \\
\hline (G5) SR24 x SR17 & 67.33 & bcde & 65.33 & $a b$ & 76.00 & $\mathrm{~b}$ & 76.00 & $a b$ & 63.33 & a & 63.33 & a \\
\hline (G6) SR25 x SR17 & 64.33 & def & 62.33 & $\mathrm{~b}$ & 76.00 & $b$ & 76.00 & $a b$ & 62.67 & a & 62.67 & a \\
\hline (G7) SR26 x SR17 & 71.33 & $a b$ & 66.33 & a & 76.67 & a & 77.67 & a & 64.67 & a & 62.67 & a \\
\hline (G8) SR30 x SR17 & 66.00 & cde & 66.33 & a & 76.00 & $b$ & 74.00 & $a b$ & 62.67 & a & 62.33 & a \\
\hline (G9) SR31 x SR17 & 61.00 & f & 64.00 & $a b$ & 76.00 & $\mathrm{~b}$ & 76.33 & $a b$ & 63.00 & a & 63.33 & a \\
\hline (G10) SR32 x SR17 & 68.33 & bcd & 67.00 & a & 76.67 & a & 74.67 & $a b$ & 63.33 & a & 62.00 & a \\
\hline (G11) SR33 x SR17 & 67.00 & bcde & 65.33 & $a b$ & 76.00 & $\mathrm{~b}$ & 75.67 & $a b$ & 62.67 & a & 62.67 & a \\
\hline (G12) SR4 x SR17 & 65.33 & def & 67.33 & a & 76.00 & $b$ & 76.67 & $a b$ & 63.67 & a & 62.33 & a \\
\hline (G13) SR41 x SR17 & 62.67 & ef & 64.33 & $a b$ & 76.00 & $\mathrm{~b}$ & 76.00 & $a b$ & 62.67 & a & 61.00 & $a b$ \\
\hline (G14) SR43 x SR17 & 68.00 & bcd & 67.33 & a & 76.00 & $\mathrm{~b}$ & 76.00 & $a b$ & 63.33 & a & 63.33 & a \\
\hline (G15) SR46 x SR17 & 70.67 & $a b c$ & 66.00 & $a b$ & 76.00 & $\mathrm{~b}$ & 75.00 & $a b$ & 64.00 & a & 63.00 & a \\
\hline (G16) SR47 x SR17 & 65.00 & def & 66.67 & a & 76.00 & $\mathrm{~b}$ & 75.00 & $a b$ & 63.00 & a & 61.33 & $a b$ \\
\hline (G17) SR52 x SR17 & 64.67 & def & 66.67 & $\mathrm{a}$ & 76.00 & $\mathrm{~b}$ & 76.33 & $a b$ & 63.33 & a & 63.67 & a \\
\hline (G18) SR9 x SR17 & 73.00 & $\mathrm{a}$ & 65.33 & $\mathrm{ab}$ & 76.00 & $\mathrm{~b}$ & 72.00 & $\mathrm{ab}$ & 62.33 & $\mathrm{a}$ & 63.00 & $\mathrm{a}$ \\
\hline
\end{tabular}

Keterangan: Angka rata-rata yang diikuti huruf yang sama menunjukkan tidak berbeda menurut uji DMRT pada taraf nyata $5 \%$. 
Tabel 4. Nilai rerata hasil (t ha-1) pada hibrida jagung manis di Jawa Barat

\begin{tabular}{|c|c|c|c|c|c|c|c|c|c|c|c|c|}
\hline Genotipe & \multicolumn{2}{|c|}{ E1 } & \multicolumn{2}{|c|}{ E2 } & \multicolumn{2}{|c|}{ E3 } & \multicolumn{2}{|c|}{ E4 } & \multicolumn{2}{|c|}{ E5 } & \multicolumn{2}{|c|}{ E6 } \\
\hline (G1)BS & 9.96 & ef & 14.46 & $a$ & 10.75 & C & 6.87 & a & 7.91 & $\mathrm{f}$ & 11.91 & $\mathrm{a}$ \\
\hline (G2) SB & 17.56 & $\mathrm{ab}$ & 11.85 & $\mathrm{a}$ & 17.75 & $\mathrm{a}$ & 6.33 & $\mathrm{a}$ & 20.73 & $\mathrm{a}$ & 9.81 & $\mathrm{a}$ \\
\hline (G3) SR15 x SR17 & 14.79 & abcd & 13.37 & $\mathrm{a}$ & 11.63 & $\mathrm{bc}$ & 9.10 & a & 14.10 & bcd & 10.87 & $\mathrm{a}$ \\
\hline (G4) SR22 x SR17 & 11.66 & cdef & 12.59 & $\mathrm{a}$ & 11.71 & bc & 7.94 & $\mathrm{a}$ & 15.46 & bcd & 10.52 & $\mathrm{a}$ \\
\hline (G5) SR24 x SR17 & 17.71 & a & 14.01 & $\mathrm{a}$ & 13.52 & $a b c$ & 8.23 & $\mathrm{a}$ & 16.53 & $\mathrm{~b}$ & 11.33 & $\mathrm{a}$ \\
\hline (G6) SR25 x SR17 & 11.45 & cdef & 12.28 & $\mathrm{a}$ & 14.61 & $a b c$ & 8.25 & $\mathrm{a}$ & 17.00 & $\mathrm{~b}$ & 9.13 & $\mathrm{a}$ \\
\hline (G7) SR26 x SR17 & 15.15 & $a b c$ & 12.86 & a & 13.35 & $a b c$ & 8.44 & a & 9.76 & ef & 10.22 & a \\
\hline (G8) SR30 x SR17 & 11.66 & cdef & 12.19 & a & 12.42 & $\mathrm{bc}$ & 8.54 & a & 15.31 & bcd & 11.08 & a \\
\hline (G9) SR31 x SR17 & 13.51 & cde & 13.63 & a & 13.99 & $a b c$ & 8.98 & a & 15.32 & bcd & 10.09 & a \\
\hline (G10) SR32 x SR17 & 12.87 & cde & 11.38 & a & 12.29 & bc & 8.77 & a & 15.34 & bcd & 11.42 & a \\
\hline (G11) SR33 x SR17 & 13.72 & cde & 14.85 & a & 12.21 & $\mathrm{bc}$ & 9.10 & a & 12.39 & de & 11.76 & a \\
\hline (G12) SR4 x SR17 & 14.72 & abcd & 10.60 & a & 14.69 & $a b c$ & 6.90 & a & 15.43 & bcd & 9.61 & a \\
\hline (G13) SR41 x SR17 & 14.86 & abcd & 11.71 & a & 13.48 & $a b c$ & 5.51 & a & 12.66 & cde & 10.42 & $\mathrm{a}$ \\
\hline (G14) SR43 x SR17 & 8.53 & $\mathrm{f}$ & 14.96 & a & 14.40 & $a b c$ & 6.90 & a & 15.34 & bcd & 9.80 & a \\
\hline (G15) SR46 x SR17 & 13.79 & bcde & 13.05 & a & 12.80 & $\mathrm{bc}$ & 6.55 & a & 13.97 & bcd & 10.64 & a \\
\hline (G16) SR47 x SR17 & 10.67 & ef & 13.21 & a & 12.41 & bc & 8.31 & a & 15.97 & $\mathrm{~b}$ & 9.23 & a \\
\hline (G17) SR52 x SR17 & 11.09 & def & 11.78 & a & 12.36 & $\mathrm{bc}$ & 8.27 & a & 14.06 & bcd & 11.47 & $\mathrm{a}$ \\
\hline (G18) SR9 x SR17 & 11.31 & cdef & 12.29 & $\mathrm{a}$ & 15.43 & $\mathrm{ab}$ & 7.52 & $\mathrm{a}$ & 16.04 & $\mathrm{~b}$ & 9.38 & $\mathrm{a}$ \\
\hline
\end{tabular}

Keterangan: Angka rata-rata yang diikuti huruf yang sama menunjukkan tidak berbeda menurut uji DMRT pada taraf nyata $5 \%$.

Interaksi $\mathrm{G} \quad \mathrm{x} \quad \mathrm{E}$ disebabkan adanya pengaruh faktor lingkungan yang berbeda. Faktor lingkungan sebagai komponen utama interaksi bisa berupa faktor lokasi, faktor musim, ataupun interaksi antar faktor lokasi dengan musim. Faktor tersebut mengakibatkan munculnya tongkol dan malai yang berbeda pada setiap lingkungan tumbuh. Hal ini menunjukkan bahwa hibrida-hibrida yang diuji memiliki respon yang berbeda terhadap lingkungan tumbuh dan berdasarkan karakter tersebut dapat dikembangkan kultivar hibrida berumur genjah yang spesifik lingkungan. Studi yang dilakukan beberapa peneliti juga mendukung adanya interaksi genotipe $x$ lingkungan (lokasi). Beberapa penelitian seperti Kuchanur et al. (2001) pada pengujian stress air pada jagung hibrida, Badu-Apraku et al. (2013) pada pengujian hibrida jagung 3 waktu pengembangan di 13 lokasi Afrika Barat, Ndhlela et al. (2014) pada pengujian hibrida jagung toleran kekeringan pada 7 lokasi Zimbabwe, dan Chimonyo et al. (2014) pada jagung bersari bebas di 5 lokasi Afrika Selatan selama 3 tahun, mengungkapkan dengan jelas adanya interaksi yang nyata antara genotipe dengan lingkungan. Ruswandi et al. (2008) melaporkan adanya interaksi genotipe dengan lingkungan pada sebelas field corn yang diuji multilokasi pada delapan lingkungan di Indonesia. Ruswandi et al. (2020) juga mendeskripsikan pentingnya interaksi $\mathrm{G} \times \mathrm{E}$ dalam seleksi hasil hibrida jagung manis di Indonesia. Walaupun interaksi genotipe dengan lingkungan menyebabkan tidak konsistennya hasil pada setiap lingkungan, namun pada kondisi tertentu, tanaman memiliki kemampuan untuk meminimalkan pengaruh lingkungan yang tidak menguntungkan, sekaligus memaksimalkan pengaruh lingkungan yang menguntungkan.

Tabel 5. Analisis GGE biplot untuk kegenjahan hibrida jagung manis Indonesia di Jawa Barat.

\begin{tabular}{|c|c|c|c|c|}
\hline \multirow[b]{2}{*}{$\begin{array}{l}\text { Sumber } \\
\text { Variasi }\end{array}$} & \multirow[b]{2}{*}{ DB } & \multicolumn{3}{|c|}{ Muncul Malai } \\
\hline & & $\begin{array}{c}\text { Kuadrat } \\
\text { nilai tengah }\end{array}$ & $\%$ & Akumulasi \\
\hline PC1 & 21 & $37.7980^{* *}$ & 58.5 & 58.5 \\
\hline PC2 & 19 & $15.4162^{* *}$ & 21.6 & 80.1 \\
\hline PC3 & 17 & $7.5318^{*}$ & 9.4 & 89.5 \\
\hline PC4 & 15 & $6.0971 \mathrm{~ns}$ & 6.7 & 96.2 \\
\hline PC5 & 13 & $2.6022 \mathrm{~ns}$ & 2.5 & 98.7 \\
\hline PC6 & 11 & $1.6108 \mathrm{~ns}$ & 1.3 & 100.0 \\
\hline
\end{tabular}

Keterangan: ** dan * masing-masing adalah berbeda nyata pada tingkat kemungkinan 0,01 dan 0,05 , ns adalah tidak berbeda nyata, DB adalah derajat bebas.

Pengaruh utama IPCA 1 terhadap interaksi G x E tersaji pada Gambar 1 dan Tabel 5 . Interaksi bilinier pertama dari analisis GGE dianalisis berdasarkan interaksi G x E, dihitung 
dari jumlah kuadrat interaksi genotipe $\mathrm{x}$ lingkungan (lokasi) dengan nilai bilinier pertama (IPCA-1) sebesar 58,50\%; 21,60\% oleh komponen IPCA-2; dan 9,40\% oleh IPCA-3. Berdasarkan Tabel 3, model GGE yang berlaku untuk membentuk biplot GGE adalah GGE-2.

Berdasarkan hasil Tabel 5 terungkap nilai jumlah kuadrat IPCA-1 dan IPCA-2 yang berbeda nyata untuk kegenjahan, berturut- turut dengan nilai akumulasi $58,5 \%$ dan $80,1 \%$.

Nilai IPCA pengaruh hibrida pada analisis GGE mengindikasikan kestabilan hibrida pada lingkungan (lokasi) tertentu. Model GGE biplot digunakan untuk menyeleksi dan mengidentifikasi genotipe potensial berdaya hasil tinggi dan adaptif terhadap lingkungan (Yan et al., 2000). Para pemulia yang telah memanfaatkan model GGE biplot diantaranya adalah Balestre et al. (2009), Tonk et al. (2011), dan Shiri (2013) pada jagung; Rao et al. (2011) pada sorghum; Farshadfar et al. (2011) pada chickpea; Mustamu et al. (2018) pada ubi jalar; dan Ruswandi et al. (2020) pada jagung manis.

Analisis GGE biplot kegenjahan hibrida jagung manis di Jawa Barat disajikan pada Tabel 5. Model GGE biplot digunakan untuk menganalisis respon genotipe pada 6 lingkungan yaitu Jatinangor musim 1 (E1) dan musim 2 (E2), Lembang musim 1(E3) dan musim 2 (E4) dan Wanayasa musim 1 (E5) dan musim 2 (E6). Visualisasi genotipe dan lingkungan dan hubungan antara keduanya tersaji pada Gambar 1.

Terdapat 3 kemungkinan hasil analisis biplot GGE, yaitu: (i) hibrida yang diuji berpenampilan lebih baik dari nilai rata-rata hibrida pada satu lingkungan bila perbandingan genotipe $(\mathrm{G})$ dan lingkungan (E) menghasilkan vektor dengan sudut lebih kecil dari $90^{\circ}$, (ii) bila sudut perbandingan G dan E yang dihasilkan lebih besar dari $90^{\circ}$ maka penampilan hibrida yang diuji lebih kecil dari pada rerata hibrida, dan (iii) bila $G$ dan $E$ membentuk sudut sama dengan $90^{\circ}$, maka penampilan hibrida sama dengan rerata hibrida pada lingkungan tersebut. Hasil analisis biplot GGE untuk interaksi $G \times \mathrm{E}$ dan adaptasi kegenjahan sejumlah hibrida di ketiga lokasi pengujian pada dua musim yang berbeda dipresentasikan pada Gambar 1a dan 1b. G15 (SR 46 × SR 17) dan G10 (SR 32 × SR 17) beradaptasi di Jatinangor E1, sedangkan hibrida G5 (SR $24 \times$ SR 17) dan G14 (SR $43 \times$ SR 17) beradaptasi di Jatinangor E2, Wanayasa E6 dan E5, dan Lembang
E3. Adapun hibrida G4 (SR $22 \times$ SR 17) beradaptasi di Lembang E4.

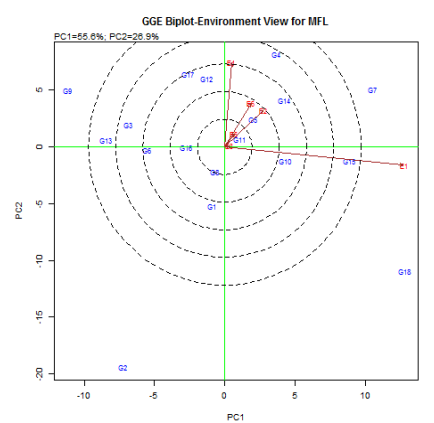

(1a)

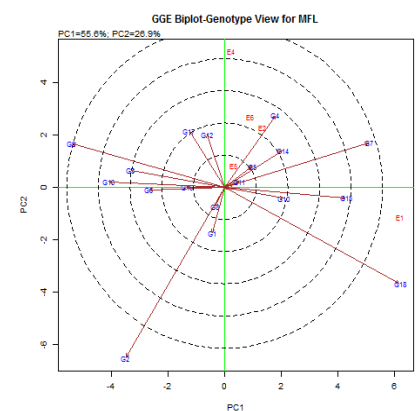

(1b)

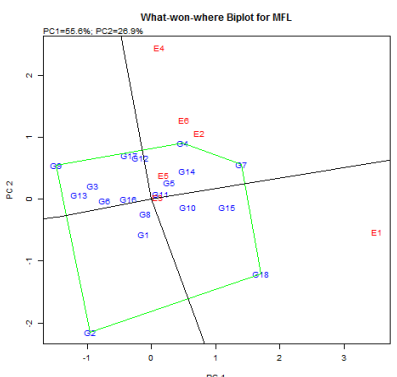

(1c)

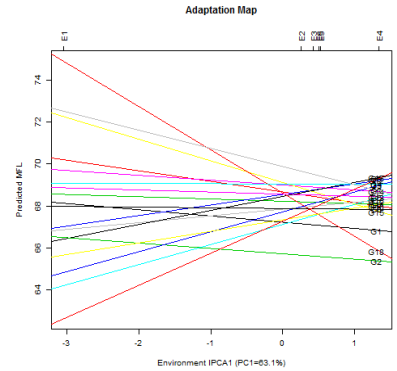

(1d)

Gambar 1: (a). Biplot GGE kegenjahan terhadap lingkungan; (b). Biplot GGE kegenjahan terhadap genotipe; (c). Biplot GGE 'what won where'; (d). Peta adaptasi kegenjahan hibrida jagung manis. G1 (BS= Bisi sweet), G2 (SB= Sweet Boy), G3 (15 x 17), G4 (22 x 17), G5 (24 x 17), G6 (25 x 17), G7 ( $26 \times 17), \mathrm{G} 8(30 \times$ 17), G9 (31 x 17), G10 (32 x 17), G11 (33 x 17), G12 (4 x 17), G13 (41 x 17), G14 (43 x 17), G15 (46 × 17), G16 (47 x 17), G17 (52 x 17), dan G18 $(9 \times 17)$. 
Biplot GGE pada Gambar 1a dan 1d dapat juga digunakan untuk mengidentifikasi kontribusi hibrida relatif terhadap $G$ atau interaksi G x E berdasarkan jarak vektor yang dibentuk genotipe tersebut. Bila suatu hibrida berpenampilan biasa saja pada setiap lingkungan, maka hibrida tersebut berkontribusi nol terhadap $G$ atau interaksi $G \times$ E. Hibrida yang memiliki jarak vektor terjauh dari titik asal memberikan kontribusi terhadap $G$ atau interaksi G. Terdapat beberapa vektor dengan jarak yang jauh dari titik nol baik yang melebihi rata-rata ataupun kurang dari rata-rata. Vektor hibrida terjauh adalah G18 yang menandakan bahwa hibrida ini yang paling genjah disemua lingkungan. Sedangkan hibrida G9 merupakan vektor terjauh pada arah berlawanan, menandakan hibrida dengan umur yang paling dalam pada semua lingkungan pengujian. Hibrida G18 merupakan hibrida yang memiliki umur genjah yang dinyatakan dengan umur munculnya malai pada ketiga lokasi pengujian pada dua musim tanam yang berbeda, kecuali di E1. Vektor terjauh pada arah berlawanan adalah hibrida G9 yang memperlihatkan umur dalam di semua lingkungan pengujian kecuali berumur genjah di E1. Sudut yang dibentuk antara vektor genotipe dan kordinat rerata lingkungan (average environment coordinate, AEC) adalah indikator $G$ atau interaksi $G \times$ E suatu genotipe. Sudut $90^{\circ}$ terhadap AEC menandakan efek $\mathrm{G} x$ E. Sebagai contoh, hibrida G12 adalah genotipe yang responnya disebabkan oleh interaksi G x E (Gambar 1a dan 1b).

Biplot "which-won-where" ditampilkan pada Gambar 1c. Biplot poligon ini disusun oleh kumpulan vektor genotipe terjauh dari asal (persimpangan nol dari sumbu $\mathrm{x}$ dan $\mathrm{y}$ ). Setiap vektor genotipe terjauh tersebut dihubungkan oleh garis lurus membentuk sebuah poligon. Menurut Chimonyo et al. (2014) dan HayosVillegas et al. (2016) suatu genotipe berpenampilan baik bila terletak pada sektor tempat berkumpulnya lingkungan pada vektor genotipe terjauh dalam suatu poligon, sedangkan genotipe terbaik adalah genotipe yang terletak tepat pada garis lurus sektor ini. Sebaliknya, suatu genotipe tidak akan berpenampilan baik apabila tidak terdapat lingkungan dalam sektor tersebut, genotipe berpenampilan terjelek adalah genotipe yang terletak tepat pada garis lurus sektor tersebut. Gambar biplot $1 \mathrm{c}$ dibagi menjadi empat sektor, dengan lingkungan E2, E4, E5, dan E6 terletak pada sektor kanan atas, sedangkan lingkungan E1 dan E3 terdapat pada sektor kanan bawah. Hibrida G4, G5, G7, G11 dan G14 berada pada sektor kanan atas, dengan hibrida G4 dan G7 merupakan hibrida genjah terbaik. Sedangkan hibrida G10, G15, dan G18 berada pada sektor kanan bawah dengan hibrida G18 sebagai hibrida genjah terbaik. Hibrida- hibrida tersebut juga memiliki daya hasil yang tinggi seperti yang ditampilkan pada Tabel 4 .

\section{Kesimpulan}

Biplot GGE merupakan metode analisis yang akurat dalam menentukan interaksi $G \times \mathrm{E}$, stabilitas dan adaptabilitas kegenjahan hibrida jagung manis. Hibrida-hibrida yang diuji memiliki respons yang berbeda pada ke-6 lingkungan tumbuh. Hibrida G4 dan G7 merupakan hibrida genjah yang beradaptasi terbaik pada lingkungan E2, E4, E5, dan E6, sedangkan hibrida G18 merupakan hibrida genjah yang beradaptasi terbaik pada lingkungan E1 dan E3. Berdasarkan informasi tersebut dapat disimpulkan bahwa hibrida G4, G7 dan G18 memiliki karakteristik berumur genjah yang spesifik lingkungan serta memiliki daya hasil yang tinggi.

\section{Ucapan Terima Kasih}

Tim peneliti menyampaikan ucapan terima kasih pada Kementrian Pendidikan Tinggi dan Riset Teknologi Republik Indonesia dan Universitas Padjadjaran yang telah membiayai penelitian dan penerbitan artikel ini melalui skema Hibah Kompetensi 2015-2017 dan Riset Kompetensi Dasar Unpad 2019-2020 yang diberikan pada Dedi Ruswandi.

\section{Daftar Pustaka}

Aruna, C., S. Rakshit, P. K. Shrotria, S. K. Pahuja, S. K. Jain, S. S. Kumar, N. D. Modi, D. T. Deshmukh, R. Kapoor, and J. V. Patil. 2016. Assesing genotype-by-environment interaction and trait associations in forage sorghum using GGE biplot analysis. The Journal of Agricultural Science. 154(1): 7386 
Badu-Apraku, B., M. Oyekunle, A. Menkir, K. Obeng-Antwi, C. G. Yallou, I. S. Usman, and H. Alidu. 2013. Comparative performance of early-maturing maize cultivars developed in three eras under drought stress and well-watered environment in West Africa. Crop Sci. 53:1298-1311.

Balestre, M., J. C. de Souza, R. G. Von Pinho, R. L. de Oliveira, J. M. V. Paes. 2009. Yield stability and adaptability of maize hybrids based on GGE biplot analysis characteristics. Crop Breeding and Applied Biotechnology. 9: 219-228

Chimonyo, V. G. P, C. S. Mutengwa, and C. Chiduza. 2014. Genotype $x$ environment interaction and yield stability of stresstolerant open-pollinated maize varieties in the Eastern Cape province, South Africa. South African journal of Plant and Soil. 31(2): 61-68.

Farshadfar, E., H. Zali, and R. Mohammadi. 2011. Evaluation of phenotypic stability in chickpea genotypes using GGE-Biplot. Annals of Biological Research. 2 (6):282-292.

Hallauer, A. R. and M. J. Carena. 2009. Maize Breeding. P.3-98. In Hand Book of Plant Breeding, Cereals. M.J. Carena (ed.). Springer-New York- DordrechtHeidelberg- London.

Hallauer, A. R., M. J. Carena, and J. B. MirandaFilho. 2010. Quantitative Genetics in Maize Breeding. Springer- New York-DordrechtHeidelberg-London.

Hoyos-Villegas, V., E. M. Wright, and J. D. Kelly. 2016. GGE biplot analysis of yield association with root traits in a Mesoamerican bean diversity panel. Crop Sci. 56: 1081-1094.

International Rice Research Institute. 2016. Plant Breeding Tools. User's Manual. Biometrics and Breeding Informatics. Plant Breeding, Genetics and Biotechnology Division

Kaya, Y., C. Palta, and S. Taner. 2002. Additive main effects and multiplicative interactions analysis of yield performances in bread wheat genotypes across environments. Turk J. Agric. For. 26: 275-279.

Kuchanur, P. H., P. M. Salimath, M. C. Wali, and C. Hiremath. 2015. GGE biplot analysis for grain yield of single cross maize hybrids under stress and non-stress conditions. Indian J. Genet. 75(4):514-517.
Mace, E. S., C. H. Hunt, and D. R. Jordan. 2013. Supermodels: sorghum and maize provide mutual insight into the genetics of flowering time. Theor Appl Genet 126: 1377-1395. https://doi.org/ 10.1007/s00122-013-2059-z

Mustamu, Y. A., K. Tjintokohadi, W. J. Grüneberg, A. Karuniawan, and D. Ruswandi. 2018. Selection of superior genotype of sweetpotato in Indonesia based on stability and adaptability. Chilean Journal of Agricultural Research. 78(4): 461-469.

Ndhlela, T., L. Herselman, C. Magorokosho, P. Setimela, C. Mutimaamba, and M. Labuschagne. 2014. Genotype x environment interaction of maize grain yield using AMMI biplots. Crop Sci. 54:1992-1999.

Nurmala, T., A.W. Irwan, A. Wahyudin, dan F.Y. Wicaksono. 2015. Agronomi Tropis. Penerbit Giratuna. Bandung.

Rad, N. M. R., M. A. Kadir, M. Y. Rafii, H. Z. E. Jaafar, M. R. Naghavi, and F. Ahmadi. 2013. Genotype $\mathrm{x}$ environment interaction by AMMI and GGE biplot analysis in three consecutive generations of wheat (Triticum aestivum) under normal and drought stress conditions. AJCS. 7(7): 956-961.

Rao, P. S, B. Rathore, B. V. S. Reddy, and S. Panvar. 2011. Application GGE biplot and AMMI model to evaluate sweet sorghum (Sorghum bicolor) hybrids for genotype $x$ environment interaction and seasonal adaptation. Indian Journal of Agricultural Sciences. 81(5): 438-44.

Rubatzky, V. E. dan M. Yamaguchi. 1998. Sayuran Dunia: Prinsip, Produksi, dan Gizi jilid 1. Penerbit ITB. Bandung.

Ruswandi, D., E. P. Anggia, E. Suryadi, S. Ruswandi, and N. Rostini. 2008. Seleksi hibrida jagung DR unpad berdasarkan stabilitas dan adaptabilitas hasil di delapan lokasi di indonesia. Zuriat. 19 (1): 71-85.

Ruswandi, D., J. Supriatna, N. Rostini, and E. Suryadi. 2016. Assessment of sweetcorn hybrids under sweetcorn/chilli pepper intercropping in West Java, Indonesia. J. Agron. 15: 94-103.

Ruswandi, D., Y. Yuwariah, M. Ariyanti, M. Syafii, and A. Nuraini. 2020. Stability and adaptability of yield among earliness sweet corn hybrids in West Java, Indonesia. International Journal of Agronomy 2020, 9 pages, https://doi.org/10.1155/20202/4341906 
Shiri, M. R. 2013. Grain yield stability analysis of maize (Zea mays L.) hybrids in different drought stress conditions using GGE biplot analysis. Crop Breeding Journal 3(2): 107112.

Silmi, F. dan M.A. Chozin. 2014. Pemanfaatan biomulsa kacang hias (Arachis pintoi) pada budidaya jagung manis (Zea sacharata Strut.) di lahan kering. J. Hort. Indonesia. 5(1): $1-9$

Subandi, S. Saenong, Zubachtirodin, dan F. Kasim. 2003. Perkembangan Penelitian
Jagung di Indonesia. Makalah dalam Lokakarya Bioteknologi Dalam Pemuliaan Tanaman di Bandung.

Tonk, F. A., E. Ilker, and M. Tosun. 2011. Evaluation of genotype $\mathrm{x}$ environment interactions in maize hybrids using GGE biplot analysis. Crop Breeding and Applied Biotechnology 11: 1-9

Yan, W., L. A. Hunt, Q. Sheng, and Z. Szlavnics. 2000. Cultivar evaluation and megaenvironment investigation based on the GGE biplot. Crop Sci. 40: 597-605. 